\title{
The Role of Local Wisdom in the Malay Folklore Mempawah as Base of Character Education on Children in Primary School (Study Folklore in West Borneo)
}

\author{
Sri Kusnita ${ }^{1}$, Sarwiji Suwandi ${ }^{1}$, Muhammad Rohmadi ${ }^{1}$, Nugraheni Eko Wardani ${ }^{1}$ \\ ${ }^{1}$ Sebelas Maret University, Ir. Sutami Stret, No. 36A, Jebres, Surakarta \\ srikusnitahidayat@student.uns.ac.id
}

\begin{abstract}
This article analyses describe the role of local wisdom which is contained in Malay folklore Mempawah in forming character education for children of elementary school. Local wisdom in society is very important because it shows customs, traditions, and cultural values which have rooted in society life of Malay Mempawah. The problem that arises in society is the lack of awareness to apply the value of local wisdom in everyday life that is actually the values contained in folklore. By understanding the Local Wisdom contained in folklore, it is expected that it can be used as a mean to form character in a child by inserting folklore in the learning material. The method used is naturalistic method by using literary anthropology approach. The data collecting technique done by the writer is direct observation, recording, interviews, and document study. The result of the research was analyzed by using interactive model data analysis that was data reduction, data display, and conclusion. The results of this study are: First, value of local wisdom relates to the society's personality (1) forgiveness, (2) togetherness value, (3) sense of responsibility and keeping promise. Second, value of local wisdom relates to customs that is tradition of buang-buang. Third, value of local wisdom relates to life equipment of society. The role of local wisdom contained in folklore as the basis of character education in elementary school is not only useful as a means of learning moral values, customs, and culture but also can be used as a means to preserve the folklore itself.
\end{abstract}

Keywords: Local wisdom, folklore, character education

\section{INTRODUCTION}

One culture in Indonesia is Malay culture that cannot be separated of Malay tribes. The unique of personal identity of the Malay tribe is differentiating it from other tribes. According Rusdi, Hermaliza, Khaira, Harvina, and Liyansyah [18] Malay people have a personality identity that can be seen from the language used, that is Malay language, using Malay customs, and is Muslim. The strong Malay tribe's character in West Borneo is Muslim. Based on the exposure, a person who claimed to be Malay Mempawah when speaking, Using customs Malay Mempawah, and religion of Islam [13]. The development of Malay culture in West Borneo is in line with the development of 
literature. Literature is part of a culture that grows and develops in the midst of society. According Suryaman [22] literature as a reflection of the socio-cultural conditions of the nation must be inherited to the young generation. Therefore, the Malay community in West Borneo especially Malay Mempawah taught values, morals, and customs to the young generation through oral literature.

Teaching about thinking and doing good deeds of tribes Malay teach it through literature because it is considered interesting and can be done anywhere. Oral literature is one of the forms of cultural expression and is part of the culture of a nation [31]. Oral literature is very diverse, one of which is folklore. Folklore is a form of oral literary work that was born and developed from a former society scattered in a relatively fixed form among certain collectives over a long time using the word cliché [3]. Furthermore Firdaus, Faizah, and Manaf [6] reveal that folklore can be interpreted as a cultural expression of a society through speech language that is directly related to various aspects of the culture and social structure of the society. In addition, in the folklore many things are contained in the life of supporters such as local wisdom [8].

Local wisdom is an attitude or behavior that seeks to keep the repertoire of culture that is the identity of the tribe of its nation [15]. Furthermore Tumanggor [27] explains that local wisdom is a life view and science and various life strategies that manifest activities undertaken by local communities in answering various problems in the fulfillment of their needs. Indonesia is a country that has a diverse cultural heritage automatically also rich in local wisdom. Furthermore Thamrin [24] explains that local wisdom is a system in the social life, political, cultural, economic, and environmental order living in the middle of society. According Setiyawan [20] local wisdom can be interpreted as a local idea that is wise, good value that is embedded and followed by members of the community. In other words, the meaning of local wisdom is the view of life and science as well as various life strategies in the form of activities undertaken by local communities in answering various problems in the fulfillment of their needs. Thamrin [25] explains the local wisdom that is in the archipelago is threatened degradation. In writing explain the role of local wisdom as the basis of character education for children in elementary school.

Character is a characteristic possessed by individuals. This characteristic is original and entrenched in the personality of the individual. According to Lickona [9] character is a good objectivity of human quality. The Characters of goodness such as honesty, courage, justice and compassion. Character is an inner standard that is implemented in various qualities of self [16]. Furthermore Fajarani [5] explains that the character of selfbased values and ways of thinking based on these values and manifest in behavior. Rahmawati [17] explains that the process of character formation must exist throughout the educational space either at home, school, or in the social environment in order to obtain maximum results.

Folklore is one of the most effective media to instill the value of character education because through folklore the basic values can be taught and can be instilled in order to form a good character in children. Parmini [12] describes that each tribe in Indonesia has many folklores and values of local wisdom which are useful for character education for children. There are some benefits that can be obtained from the using of folklore for 
character education, including as the value of spirit and also can be useful as a mean to conserve the existence of the folklore itself.

Folklore studied is a folktale from Mempawah District of West Borneo Province. Telling local folklore especially Mempawah Melayu story is a means to introduce folklore to the students. Thus this way can be used to preserve local literature in order not to be forgotten by the younger generation. Based on data from the Central Bureau of Statistics of West Borneo Province in 2016, the area of Mempawah Regency has an area of $0,87 \%$ of the total area in West Borneo with geographical location 0042'53 "LU000'34" LU and 108034'31 "BT-110022'46 "BT.

Past research related to local wisdom has been done by Saleh in 2013 [19] with the title "Local Wisdom of Kaili Community in Central Sulawesi". In Saleh's research focused on the local wisdom of forest preservation and living equipment. Furthermore, Thamrin in 2013 [24] conducted a research entitled "Local Wisdom in Environmental Sustainable Environmental Wisdom (The Local Wisdom in Environmental Sustainable) this research described that Malay society was full of cultural wisdom value in maintaining their environment, which could be seen from the utterances of spells, advice, poetry, and petatah petitih in daily traditional life. The similarity of the previous study and this study is on their study that is both of them study about the local wisdom existed in the society, whereas the difference is the focus of the local wisdom study. In this study, the society local wisdom becomes the base of character education for children of Elementary School.

\section{METHOD}

The method used in this research is a naturalistic method with literary anthropology approach. Endraswara [4] reveals that literary anthropology belongs to the archetypal approach, literature studies that emphasize past cultural heritage. The data in this study is Malay Mempawah folklore spoken by the narrator which is then changed in written form. Sources of research data are informants who come from the community have stories and documents related to Malay Mempawah folklore. Data collection techniques were done by direct observation, recording, interviews, and document review. The results were analyzed refers to Miles and Huberman [10] interactive model analysis consists of three important components. Firstly, data reduction, means summarizing, selecting, and focusing on some important things, for examples clarifying the local wisdom which is related to personality value, customs and live equipment obtained from the field note. Secondly, data display can be done in the form of description, chart, relation between categories, etc. thirdly, conclusion drawing through drawing and verification, then the result of verification is adjusted to the problem statement. The presented conclusion is based on some problem in the study. This activity is ended by re checking the whole process from data collection until drawing conclusion and verification to get an accurate result of analysis and conclusion. Verification is done by communicating the research data obtained with informants who have provided information about Malay people folklore Mempawah West Borneo. 


\section{RESULT AND DISCUSSION}

Since ancient times Malay Mempawah ancestors have added the value of local wisdom to the next generation through folklore. Folklore is a reflection of the lives of past societies that must be known by the successor community [11]. The value of local wisdom possessed by the community can also be used as a basis in character education such as polite satun, honesty, sense of togetherness, mutual cooperation [32]. Furthermore, according to Thamrin [26] the local wisdom of Malays is not only in the form of customary values and norms, but also in the activities and the use of technology in everyday life. Malay folklore Mempawah in it contained local wisdom that can be used as a material of learning in the school especially elementary school because it can form the character of children to be better. The value of character education in children is a provision to become a man of noble character. One of the variables which is important in terms of character education is childs experiences, the child makes right decisions and gains the ability which is required for his adjustment to the changing environment [28]. The statement is in accordance with thought Wassid [30] the psychology of child development of elementary school aged children cannot be said only from their emotion without considering their environment. The influence of extrinsic factors on a child is very strong through admiring some story figures based on either direct or indirect experience, thus the child will form an ideal self-concept for themselves. Therefore, an interesting story for a student can influence his character forming inside him. This is why folklore can be the basis of character education in elementary school because at this stage it is an early stage to develop an attitude by teaching children good value through interesting things. The local wisdom analyzed in this study deals with personality, customs, and living tools because they are the closest and often seen by the students.

\section{Local Wisdom Malay Folklore Mempawah associated with the Personality Values of the Community}

\section{The nature of forgiveness}

The value of the forgiving nature of Malay Mempawah storyline is contained in the story "Buaya Kuning" note the following quotation.

"Well, forgive that young man; because he was innocent and unconventional shoot me". The princess said. "yes you may", with the terms die must work in palace as your advisor". The king said. The princess who heard the words of the father immediately agreed.

The quote above explains that the princess has a forgiving nature, for not punishing the young man who shot his foot. According Syuriadi, Hasanuddin, and Ngusman [23] forgiving is included in the value of care education. Caring values are those who want to always forgive and help others. The nature of forgiveness should be instilled in the learner's psyche. This is so that they do not have the nature of revenge. 


\section{Togetherness Value}

A sense of togetherness is contained in Robo-Robo story. Notice the following quotation.

"After doing the prayer, followed by eating together. The process that is then used as the beginning of robo-robo activity day every year done by Mempawah residents, by eating outside the house with relatives and neighbors".

Based on the above quotation it is clear the value of togetherness Malay Mempawah community at robo-robo event. The event is an annual event conducted to commemorate the arrival of OPU Daeang Manambon in Mempawah and became the first Islamic king in that area. According Purwaningsih [14] in the activity showed members of the community to eat together to see the intimacy among members of the community. The value of togetherness shows fellow solidarity honoring differences between members of society, equality, and creating peace.

\section{Responsibility}

The sense of responsibility that the story character possessed is reflected in the story of "King Kudong and Queen Banyu". Notice the passage below.

"The king was reluctant to leave his wife and children for being so loving and unlucky to them. The obligation as a king makes the King of Kodung must return to land to fulfill his duty as a king”.

The quote above shows the sense of responsibility and willing to sacrifice King Kudong as king despite having to leave his wife and child. According to Judiani [7] responsibility is the attitude and behavior of a person to carry out duties and obligations that must be done against yourself, society, environment (nature, social, and culture). This important story is taught to children to always be responsible with their obligations as students [12]. In this story also shows the value of keeping promises. Examples of quotes in the story that show the attitude of keeping promises.

"When will be separated, Princess Banyu advised that if found yellow crocodile in the river upstream, then do not disturb, because the yellow crocodile is a descendant of marriage between King Kodung and Princess Banyu. The king holds the message of his wife ".

Keeping the promise in the story gives a moral message to the students to always keep the promises they have made either with friends or with others.

\section{Local Wisdom Malay Folklore Mempawah associated with the Customs}

The customs of Malay traditional tradition of Mempayu that still exist until now is wasted ceremony. This tradition must be preserved and introduced to the young generation in order not to be forgotten. This waste tradition is contained in the story of "King Kudong and Queen Banyu". Notice the quote below. 
"When King Kudong longs for his wife and children and wants to meet them, then prepared the equipment that has been said earlier to be spread in Sungai Mempawah. Appears some yellow crocodiles approaching the king. Based on the story makes the descendants of the kraton of Mempawah continue to hold (preserve) the waste of that event ".

The wasting tradition is considered sacral by the Malay Mempawah community, hitherto the people still practice this tradition every year. According to Umberan et.al. [29] waste is a ritual disposal to the estuary Mempawah river. The discarded offerings consisted of yellow rice that symbolized prosperity and prosperity and stature and stature symbolizes blessing.

\section{Local Wisdom Malay Folklore Mempawah associated with the Living Equipment Society}

The Story of The Origin The name Kijing Beach tells the life of the fisherman who became the livelihood of some Mempawah people. Notice the quote below.

"Finally the Molpun desperate to go with his father's boat that has long been used and fragile. Up in the middle of the sea, the mole just saw a vast expanse of sea and some floating pieces of wood scattered. He picked up the pieces of wood and was shocked that the fragments were the remains of his blighted boat crashing waves and storms."

Equipment of Mempawah community life is a sampan because of the lower Regency including coastal area and also in Aliri River so some people work as fisherman. The equipment still used by Malay Mempawah community is like a quote in the story as follows.

"When King Kodung wants to meet his wife and son, King Kodung must throw raw chicken eggs, nails, pecan, a flock of betel, a handful of berteh and yellow rice that has been smeared perfume and thrown into the river".

The above equipment is still used in Malay Mempawah community in daily life. Chicken eggs, nails, and berth are usually used for medical treatment while yellow rice is used customary events such as wedding, moving house, and hair clippers. Character education claimed that the beneficial learning experience they obtained not only in developing ethical, experiential, and intellectual foundation of character, but also those experiences continue extending thorough out their lives [1]. 


\section{CONCLUSION}

Based on the findings of research on local wisdom in Malay Mempawah folklore which became the basis of character education in elementary school children can be concluded as follows. First, the value of local wisdom is related to the personality of the community (1) the nature of forgiveness, (2) the value of togetherness, (3) the sense of responsibility and keeping the promise. Secondly, the value of local wisdom is related to the traditional Malay Mempawah society which is a waste tradition. Thirdly, the value of local wisdom is related to the living equipment of the community, namely the canoe. According Syuriadi, Hasanuddin, and Ngusman [23] the values of local wisdom applied by future generations can guarantee nationalism and the existence of a clear identity owned by the younger generation. Furthermore it can also introduce special traits that are strongly attached to the traditional area. Malay folklore Mempawah that contains the value of local wisdom can be taught in schools that beneficial to shape character of students to be better. Therefore, the expected local wisdom contained in the folklore can be used as the basis of character education in primary school children. Skaggs and Bodenhorn [21] suggested the importance of the process of implementation of character education in different districts in order to fit the needs and goals of each community, thereby effectively influencing students' behaviors. The role of local wisdom in folklore Mempawah Melayu can be used as a mirror of behavior in an effort to increase emotional intelligence through character education. In addition, it is also useful as a means to study moral values, customs, and culture and can be used as a means to preserve the folklore itself in order not to be forgotten by the young generation.

\section{REFERENCES}

[1] Agboola, A. and Tsai, K.C. 2012. "Bring Character Education into Classroom". European Journal of Educational Research. Vol. 1, No. 2,:163-170.

[2] BPS Kalimantan Barat. 2016. Kalimantan Barat dalam Angka 2016. Badan Pusat Statistik Provinsi Kalimantan Barat.

[3] Danandjaja, J. 2007. Folklore Indonesia, Ilmu Gosip, Dongeng, dan Lain-lain. Jakarta: Pustaka Utama Grafiti.

[4] Endraswara, S. 2008. Metodologi Penelitian Sastra. Yogyakarta: Media pressindo.

[5] Fajariani, U. 2014. Peranan Kearifan Lokal dalam Pendidikan Karakter. Jurnal Sosio Didaktika: Vol. 1, No. 2 Desember 2014.

[6] Firdaus, M., Faizah, H., dan Manaf, N.A. 2013. Cerita Rakyat Masyarakat Rambah Kabupaten Rokan Hulu Provinsi Riu. Jurnal Bahasa, Sastra, dan Pembelajaran. Vol. 1. No. 2, Juni 2013.

[7] Judiani, S. 2010. "Implementasi Pendidikan Karakter di Sekolah Dasar Melaui Penguatan Pelaksanaan Kurikulum”. Jurnal Pendidikan dan Kebudayaan, Vol. 16, edisi khusus III, Oktober 2010.

[8] Kleden, I. 2004. Sastra Indonesia dalam Enam Pertanyaan: Esai-esai Sastra dan Budaya. Jakarta: Pustaka Utama Grafiti.

[9] Lickona, T. 2015. Character Matters (Persoalan Karakter): Bagaimana Membantu Anak, Mengembangkan Penilian yang Baik, dan Kebajikan Penting Lainnya. Jakarta: Bumi Aksara.

[10] Miles, M \& A. M. Huberman. 2014. Analisis Data Kualitatif. Bandung: UI-Press.

[11] Normaliza, A. R. 2014. The nearly forgotten malay folklore: shall we start with The software? TOJET: The Turkish Online Journal of Educational Technology - July 2014, volume 13 issue 3. 
[12] Parmini, P.N. 2015. "Eksistensi Cerita Rakyat dalam Pendidikan Karakter Siswa SD di Ubud". Jurnal Kajian Bali, Vol. 05, No 02, Oktober 2015.

[13] Purba, J., Alqadrie, Syf. I., Hermansyah, Yusriadi, dan Ahyat. I.S. 2011. Sejarah Penyebaran dan Pengaruh Budaya Melayu di Kalimantan. Jakarta: DirJen Sejarah dan Purbakala, Kementrian Kebudayaan dan Pariwisata.

[14] Purwaningsih, E. 2006. "Permainan Tradisional Anak: Salah Satu Khasanah Budaya yang Perlu Dilestarikan”. Jantra Vol. 1, No. 1, Juni 2006.

[15] Rafiek, M. 2012. "Kearifan Lokal dalam Hikayat Banjar". International journal of the Malay World and Civilisation (Iman)Vol. 30, No. 1, 2012, : 67-104.

[16] Raharjo, S.B. 2010. "Pendidikan Karakter Sebagai Upaya Menciptakan Akhlak Mulia”. Jurnal Pendidikan dan Kebudayaan. Vol. 16, No. 3, Mei 2010.

[17] Rahmawati. 2015. "Cerita Rakyat Makassar sebagai Media Pembentukan Karakter". Jurnal Jatra, Vol. 10, No. 2, Desember 2015.

[18] Rusdi, P., Hermaliza, E, Khaira, Hravina, dan Liyansyah, M. 2013. Nilai-Nilai Budi Pekerti yang Terkandung dalam Cerita Rakyat Melayu di Sumatera. Banda Aceh: Kementrian Pendidikan dan Kebudayaan Balai Pelestarian Nilai Budaya Banda Aceh.

[19] Saleh. 2013. "Kearifan Lokal Masyarakat Kaili di Sulawesi Tengah". Jurnal Academica Fisip Untad. Vol. 05 No. 02 Oktober 2013, hal. :1126-1134

[20] Setiyawan, A. 2012. "Budaya Lokal dalam Perspektif Agama: Legitimasi Hukum Adat (U'rf) dalam Islam”. Jurnal Esensia Vol. XIII No. 2 Juli 2012, Hlm. 203-221.

[21] Skaggs, G and Bodenhorn, N. 2006. Relationships Between Implementing Character Education, Student Achievement. Journal of Advanced Academics, 18(1), 82-114.

[22] Suryaman, M. 2010. Pendidikan Karakter Melalui Pembelajaran Sastra. Cakrawala Pendidikan, Mei 2010, Tn. XXIX, Edisi Khusus Dies Natalis UNY.

[23] Syuriadi, H., Hasanuddin, dan Ngusman, Ws. 2014. Nilai-Nilai Pendidikan dalam Teks Cerita Randai "Malangga Sumpah" Karya Lukman Bustami Grup Randai BintangTampalo Kenagarian Pdang Lawh Kabupaten Sijunjung. Jurnal Bahasa Sastra dan Pembelajaran. Vol. 2, No. 2, Juni 2014.

[24] Thamrin. 2013. "Kearifan Lokal dalam Pelestarian Lingkungan (The Lokal Wisdom in Environmental Sustainable)". Jurnal Kutubkhanah, Vol.16, No. 1 Januari 2013, Hal. :46-56.

[25] Thamrin. 2014. "Marjinalisasi Tanah Adat dan Kearifan Lingkungan Orang Melayu". Jurnal Sosial Budaya; Media Komunikasi Ilmu-Ilmu Sosial dan Budaya, Vol. 11, No. 1 Januari-Juni 2014.

[26] Thamrin, H. 2014. "Revitalisasi Kearifan Lokal Melayu dalam Menjaga Harmonisasi Lingkungan Hidup”. Jurnal Toleransi: Media Komunikasi Umat Beragama, Vol. 6, no. 1 Januari-Juni 2014.

[27] Tumanggor, R . 2007. "Pemberdayaan Kearifan Lokal Memacu Kesetaraan Komunitas Adat Terpencil”. Jurnal Penelitian dan Pengembangan Kesejahteraan Sosial, Vol. 12, No. 01, 2007: 9-12.

[28] Turan, F and IIkay, U. 2016. Using Stroybooks as a Character Education Tools. Journal Of Education and Practice. Vol. 7, No. 15, 2016.

[29] Umberan, M. et.al., 1996. Kerajaan-kerajaan di Kalimantan Barat. Pontianak: Balai Kajian Sejarah dan Tradisional Pontianak.

[30] Wassid, I. 2009. Strategi Pemebelajaran Bahasa. Bantung: Remaja Rosda Karya.

[31] Yohana, N. dan Kurnia, H. 2015. "Kaidah Interaksi Komunikasi Tradisi Lisan Baslacuang dalam Adat Perkawinan Melayu Kampar Riau". Jurnal Penelitan Komunikasi. Vol. 18, No. 1, Juli 2015: 43-56.

[32] Yunus, R. 2012. Nilai-Nilai Kearifan Lokal (Local Genius) Sebagai Penguat Karakter Bangsa. Yogyakarta: Deepublish. 